EISSN: 2706-7955 ISSN: 2077-4605

DOI: $10.36632 /$ mejar/2021.10.2.34

Journal homepage: www.curresweb.com

Pages: 493-500

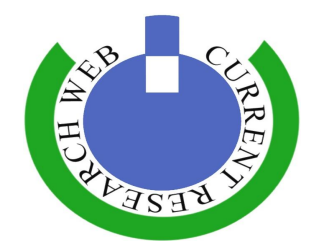

\title{
Growth, Productivity and Quality of Certain Seedling Dry Date Palm in Comparison with Bartamuda cv. in Aswan, Egypt
}

\section{O. A. Khalil ${ }^{1}$ and Manal A.M. Hassan ${ }^{2}$}

${ }^{I}$ Tropical Fruits Dept., Hort. Res. Inst., ARC, Egypt.

${ }^{2}$ Food Sci. and Technol., Fac. of Agric., Assiut Univ., Assiut 71526, Egypt.

Received: 15 March $2021 \quad$ Accepted: 20 April $2021 \quad$ Published: 25 April 2021

\begin{abstract}
The present study was conducted during the 2019 and 2020 seasons with the aim of studying the performance of nine seedling strains of dry date palm and comparing them with Bartamuda cv. located in Banban village, Daraw City, Aswan Governorate. Data showed that ninth, fifth, and first strains were superiorin leaf length compared to other strains and Bartamuda. The tallest leaflets were recorded in Bartatmuda, followed by the first and fifth seedling strains. Bartatmuda, followed by the first strain, resulted in the best results for the yield/ palm compared to other date palm for both seasons. Bartamuda, followed by the fourth and eighth strains were the highest in total sugars $\%$ of fruits compared to other strains. However, the highest values of the fruit weight were noticed with the sixth, eighth, third, and first strains compared to Bartamuda in the first and second seasons, respectively. Bartamuda was superior in terms of productivity and quality as it attained the uppermost score units (90/100) compared to other seedy strains in the same region. It can be concluded that some of seedling strains surpass Bartamuda in some of the fruit quality traits such as the third, fourth, eighth, and the first strains.
\end{abstract}

Keywords: Seedling strains, dry date palm, Bartamuda cv., vegetative, physical and chemical characteristics.

\section{Introduction}

Date palm is one of the fruit trees that have been known since ancient times in the countries of the Middle East, which play a vital role as food and is a strategic crop in both the food and biochemical industries (Khayyat et al., 2007). Nowadays, Egypt is occupying an advanced position in the world in the production of good dates. Indeed, the political leaders and the Ministry of Agriculture are interested in increasing the local production of them to increasing the national income. The seedling strains of date palms are the most widespread in Egypt, however, there are many of these strains that give high production specifications in some times, so the evaluation process for these strains aims to reach the identification of these strains and work to spread it's cultivation through tissue culture technique.

Hussein et al. (1979) recorded that Aswan Governorate is considered one of the most important areas in Egypt for the production of dry cultivars of date palms. However, date palm cultivars are divided into three groups according to the moisture content of the fruit, which are soft (more than 30\%), semidry (20-30\%) and dry (less than 20\%). However, some of the seedling strains of date palm in Aswan Governorate have been evaluated with some important studies (Khalil, 2005). In this respect El-Salhy et al. (2016) evaluated certain seedy dry date palm and found that there were some seedling strains, such as KhaledIbn Al-Walid, Al-Masry 2, Ali Amer, Abbas Jafar and Al-Masry 1, which are among the most promising strains, from which high productivity and good quality characteristics are obtained when compared with the Sakkoty date palm cultivar.

Evaluation of date palm cultivars or seedy strains depends upon certain characteristics. These characteristics include: the morphological characteristics of the trees, physical and chemical characteristics of the fruit, through which it is possible to identify important information that helps in

Corresponding Author: O. A. Khalil, Tropical Fruits Dept., Hort. Res. Inst., ARC, Egypt 
obtaining superior productivity palms of high quality (Rokba et al., 1990; El-Sharabasy et al., 2003; Jaradate and Zaid, 2004; Ismail et al., 2006; Gadalla, 2013; El-Salhy et al., 2016). Therefore, this study was conducted to evaluate the performance of nine palm strains produced by seedlings (sexual propagation) and Bartamuda cv. palms that produced by offshoots (vegetative propagation). Such evaluation included the vegetative parameters, yield, and fruit characteristics.

\section{Materials and Method}

This work was conducted during the seasons of 2019 and 2020 with the aim of studying the performance of nine seedling strains of dry date palm and comparing them with Bartamuda $\mathrm{cv}$. in Bamban village at Daraw City, Aswan Governorate. These nine seedling strains were produced through sexual propagation. palms were in the same growth vigor, healthy, 25 years old and planted at $8 * 8$ meter apart .All chosen palms received common horticulture practices which done annually in the orchard. Palms were pollinated throughout two seasons by a known male palm with high viable pollen grains (after tested with acetocarmen dye). Pollination was applied at 2 days upon spathe cracking according to Hussein et al. (1979).

\subsection{Vegetative characteristics}

After harvesting for each season, the palm height $(\mathrm{m})$ was estimated from the surface of the soil to the top of the tree. The palm girth $(\mathrm{m})$ was measured at a height of 1 meter above the soil surface in meters. Four leaves were randomly detached from each palm to measure leaf length, leaflet length, zone of leaflet $\%$ and zone of spines. Leafet area $=$ leaflet length $\mathrm{x}$ maximum width $\mathrm{x} 0.84$ (Shabana and Anton, 1980).

\subsection{Yield}

In the two seasons of the study, and in the tamr stage at September 15, the number of bunch/ palm, and the average weight of the bunch are measured, from which the yield of each palm is calculated.

\subsection{Fruit quality}

After harvesting the crops for both seasons, 15 fruits were taken from each palm tree, in order to assess the chemical and physical properties of the fruit.

\subsection{Chemical properties}

The most important chemical characteristics have been appreciated during the two consecutive seasons to determine the quality characteristics as follows:

\subsubsection{Total soluble solids (T.S.S) content (\%)}

Total soluble solids (TSS) was determined in fruit juice using a hand refractometer (A.O.A.C., 1995).

\subsubsection{Sugars content $(\%)$}

Total sugars percentages and reducing sugars were determined according to the method of Lane and Eynon volumetric method as described in the A.O.A.C. (1995) and non-reducing sugars were then calculated.

\subsubsection{Total acidity content $(\%)$}

Fruit acidity was determined by using $10 \mathrm{ml}$. of fruit juice which was titrated against sodium hydroxide using phenolphthalein as indicator according to official methods (A.O.A.C., 1995) and the total acidity was calculated as citric acid (Mawlood, 1980).

\subsection{Physical characteristics}

Physical characteristics of fruits were determined during the 2019 and 2020 seasons; the most important physical characteristics studied were fruit weight $(\mathrm{g})$, flesh and seed weight $(\mathrm{g})$, fruit length $(\mathrm{cm})$ and fruit diameter $(\mathrm{cm})$ using digital caliper. 


\subsection{Statistical analysis}

The experiment was set in a complete randomized design with three replicates and one tree for each replicate. Statistical analysis of the obtained results was carried according to Snedecor and Cochran (1980). L.S.D. test was used for comparing the means at the $5 \%$ level of probability.

\section{Results and Discussion}

\subsection{Vegetative characteristics}

Data in Tables $(1 \& 2)$ showed the vegetative characteristics of nine seedling strains of dry date palm compared to the Bartamuda cv. during the 2019 and 2020 seasons. Through the recorded results, it was evident that there were significant differences between these seedling strains and Bartamuda for vegetative parameters. The third seedling strain were recorded the highest values of palm height (14.18 $\& 14.26 \mathrm{~m})$ and fourth $(13.59 \& 13.63 \mathrm{~m})$, in compared to other palms, including Bartamuda (13.42 \& $13.49 \mathrm{~m}$ ) in the first and second seasons, respectively.

Table 1: Some of vegetative parameters of certain seedy dry palms and Bartamuda cv. under Aswan conditions during 2019 and 2020 seasons.

\begin{tabular}{ccccccccc}
\hline $\begin{array}{c}\text { Character } \\
\text { Seedling No. }\end{array}$ & \multicolumn{2}{c}{$\begin{array}{c}\text { Palm height } \\
(\mathbf{m})\end{array}$} & \multicolumn{2}{c}{$\begin{array}{c}\text { Palm girth } \\
(\mathbf{m})\end{array}$} & \multicolumn{2}{c}{$\begin{array}{c}\text { Leaf length } \\
(\mathbf{m})\end{array}$} & \multicolumn{2}{c}{$\begin{array}{c}\text { Leaflet length } \\
(\mathbf{c m})\end{array}$} \\
\hline & $\mathbf{2 0 1 9}$ & $\mathbf{2 0 2 0}$ & $\mathbf{2 0 1 9}$ & $\mathbf{2 0 2 0}$ & $\mathbf{2 0 1 9}$ & $\mathbf{2 0 2 0}$ & $\mathbf{2 0 1 9}$ & $\mathbf{2 0 2 0}$ \\
\hline Seedling 1 & 12.38 & 12.44 & 1.69 & 1.71 & 4.25 & 4.25 & 56.25 & 56.66 \\
Seedling 2 & 10.42 & 10.48 & 1.33 & 1.34 & 2.55 & 2.55 & 54.35 & 54.69 \\
Seedling 3 & 14.18 & 14.26 & 1.83 & 1.84 & 3.70 & 3.69 & 43.04 & 43.20 \\
Seedling 4 & 13.59 & 13.63 & 1.80 & 1.81 & 4.00 & 3.98 & 49.21 & 50.17 \\
Seedling 5 & 12.38 & 12.43 & 1.80 & 1.82 & 4.31 & 4.29 & 55.58 & 55.70 \\
Seedling 6 & 12.45 & 12.51 & 1.50 & 1.52 & 3.74 & 3.71 & 46.01 & 46.90 \\
Seedling 7 & 13.40 & 13.47 & 1.59 & 1.60 & 3.76 & 3.74 & 51.15 & 52.37 \\
Seedling 8 & 12.52 & 12.60 & 1.84 & 1.87 & 3.70 & 3.72 & 48.67 & 48.74 \\
Seedling 9 & 12.50 & 12.57 & 1.81 & 1.83 & 4.58 & 4.60 & 45.49 & 46.77 \\
Bartamuda cv. & 13.42 & 13.49 & 1.91 & 1.94 & 3.78 & 3.78 & 60.15 & 60.07 \\
\hline LSD 5\% & 0.22 & 0.22 & 0.12 & 0.12 & 0.12 & 0.13 & 5.55 & 5.58 \\
\hline
\end{tabular}

Table 2: Some of vegetative parameters of certain seeded dry palms and Bartamuda cv. under Aswan conditions during 2019 and 2020 seasons.

\begin{tabular}{ccccccc}
\hline $\begin{array}{c}\text { Character } \\
\text { Seedling No. }\end{array}$ & \multicolumn{2}{c}{$\begin{array}{c}\text { Spine length } \\
\text { (cm) }\end{array}$} & \multicolumn{2}{c}{ length of leaflets area } \\
\% & \multicolumn{2}{c}{ length of spines area } \\
\%
\end{tabular}

The highest values of the palm girth were obtained in the Bartamuda cv., followed by the third and ninth seedy strains, while the second and sixth recorded the lowest values as an average of two 
seasons. The ninth, followed by fifth, and first were surpassed the rest of strains and Bartamuda cv. in the leaf length, while the lowest values were recorded with the second strain. Moreover, the largest values of leaflet length were obtained in the Bartamuda cv., followed by the first and fifth strains, while the third and ninth recorded the shortest leaflets in the average of seasons.

Eighth, second, and third palm strains were recorded the highest values of the spine length compared to others, including Bartamuda, while the shortest spines for the sixth and first ones in the average two seasons. Based on the measurements of length of the leaflets area percentage, it is clear from table (2) that the tallest area was associated with the third $(86.68 \& 86.70 \%)$, and ninth $(83.04 \&$ $83.17 \%)$ strains compared to the Bartamuda (77.08 \& $77.10 \%)$ in the first and second seasons, respectively. Meanwhile, the Bartamuda and fifth strain were excelled for length of spines area to other palms, while the lowest values were recorded with the third and ninth strains for both seasons.

Data of our results proved that some of seedy strains has higher palm height, leaflets area percentage, the spine length compared to other palms, including Bartamuda. Meanwhile, the highest values of palm girth, leaflet length, and length of spines area were obtained in the Bartamuda compared to other palms. These results were in accordance with the finding of Abdalla (1986); Nour et al. (1986); Khalil (1999); Khalil (2005) on such palms at same Aswan location and Abd-El Hamed et al. (2017) on seedlings soft date palm.

\subsection{Yield components}

Data in Tables (3) showed the yield components for nine seedling strains of dry date palm compared to the Bartamuda cv. during the 2019 and 2020 seasons. It was noticed that there were significant differences between these seedling strains and Bartamuda for the yield components. The first strain was recorded the highest values of the number of bunches ( $22.66 \& 22.33)$, followed by Bartamuda $(21.0 \&$ 19.33), while the eighth and sixth strains recorded the lowest ones compared to other palms in the average both seasons. When comparing the average weight of the producing bunches of the palms under study, it became clear that, there were more than one strain that recorded the heaviest bunches compared to the Bartamuda, of these superior seedlings, eighth(10.0 \& 9.50), fourth $(8.16 \& 8.13)$ and sixth (7.53 \& $7.73 \mathrm{~kg}$ ) strains. Meanwhile, the lightest bunches were recorded with the first, second, and fifth seedling strains in the average of seasons. As for the yield/ palm, Bartatmuda, followed by the first strain, produced the highest yield compared to other date palm for both seasons. While the lowest productivity coincided with the fifth, sixth, and second strains.

Table 3: Yield components of certain seeded dry palms and Bartamuda cv. during 2019 and 2020 seasons.

\begin{tabular}{ccccccc}
\hline $\begin{array}{c}\text { Character } \\
\text { Seedling No. }\end{array}$ & \multicolumn{2}{c}{ Number of bunches } & \multicolumn{2}{c}{$\begin{array}{c}\text { Average weight of } \\
\text { bunch (kg) }\end{array}$} & \multicolumn{2}{c}{$\begin{array}{c}\text { Yield/ palm } \\
\text { (kg) }\end{array}$} \\
\hline & $\mathbf{2 0 1 9}$ & $\mathbf{2 0 2 0}$ & $\mathbf{2 0 1 9}$ & $\mathbf{2 0 2 0}$ & $\mathbf{2 0 1 9}$ & $\mathbf{2 0 2 0}$ \\
\hline Seedling 1 & 22.66 & 22.33 & 5.43 & 5.40 & 122.30 & 147.20 \\
Seedling 2 & 17.00 & 15.33 & 5.60 & 5.65 & 89.53 & 86.61 \\
Seedling 3 & 11.66 & 16.00 & 6.33 & 6.36 & 105.33 & 101.80 \\
Seedling 4 & 12.00 & 11.66 & 8.16 & 8.13 & 95.33 & 94.80 \\
Seedling 5 & 15.66 & 14.66 & 5.55 & 5.86 & 87.02 & 86.00 \\
Seedling 6 & 11.66 & 11.33 & 7.53 & 7.73 & 87.90 & 87.56 \\
Seedling 7 & 14.00 & 13.00 & 7.23 & 7.43 & 101.10 & 96.53 \\
Seedling 8 & 9.00 & 10.00 & 10.00 & 9.50 & 90.00 & 95.00 \\
Seedling 9 & 13.00 & 12.33 & 7.30 & 7.76 & 94.73 & 95.70 \\
Bartamuda cv. & 21.00 & 19.33 & 7.33 & 7.73 & 153.83 & 149.33 \\
\hline LSD 5\% & 1.80 & 1.28 & 0.35 & 0.34 & 8.24 & 25.56 \\
\hline
\end{tabular}

Palm productivity is the function of several factors such as spathes number per palm, fruit set and average fruit weight. Generally palm yield was found to be higher in Bartamuda palms compared to seedling ones. Khalil (2005) revealed that the greater reduction in palm yield due to sexual propagation was more pronounced in Sakkoti followed by Bartamuda, while the least reduction was found in Malakaby. Although, the commercial harvesting date of palms produced from seedlings was later than 
vegetatively produced ones, it was within harvesting periods reported by other scientists at same location (Hussein 1970, Hussein et al., 1979 and El-Agamy et al., 2001; Abd-El Hamed et al., 2017).

\subsection{Chemical characteristics of fruits}

Data in Tables (4) showed the chemical characteristics of fruits for nine seedy strains of dry date palm in comparison to the Bartamuda cv. during the 2019 and 2020 seasons. It was noticed that there were significant differences between these palms for these chemical characteristics in both seasons. As for total soluble solids, the highest values were recorded with the eighth $(76.30 \& 75.33)$ and fourth strains (74.26 \& 74.66), followed by Bartamuda (73.03 \& $72.70 \%)$, while the second and fifth strains recorded the lowest ones compared to other palms as an average of seasons. As well as Bartamuda c.v recorded the highest values of total sugars $(68.66 \& 68.10 \%)$ followed by the fourth and eighth strains compared to the rest of strains under study as an average of two seasons. As for the reducing sugar $\%$ of fruits, the eighth strain, Bartatmuda followed by the sixth strain, recorded the highest values compared to other date palm for both seasons. While the lowest reducing sugar percentage was coincided with the second, seventh, and first strains.

Table 4. Chemical characteristics of fruits of certain seeded dry palms and Bartamuda cv. during 2019 and 2020 seasons.

\begin{tabular}{cccccccccccc}
\hline $\begin{array}{c}\text { Character } \\
\text { Seedling No. }\end{array}$ & $\begin{array}{c}\text { Total Soluble } \\
\text { Solids \% }\end{array}$ & \multicolumn{2}{c}{$\begin{array}{c}\text { Total sugars } \\
\text { \% }\end{array}$} & \multicolumn{2}{c}{$\begin{array}{c}\text { Reducing } \\
\text { sugars \% }\end{array}$} & \multicolumn{2}{c}{$\begin{array}{c}\text { Total } \\
\text { acidity\% }\end{array}$} & \multicolumn{2}{c}{$\begin{array}{c}\text { Non reducing } \\
\text { sugars \% }\end{array}$} \\
\hline & $\mathbf{2 0 1 9}$ & $\mathbf{2 0 2 0}$ & $\mathbf{2 0 1 9}$ & $\mathbf{2 0 2 0}$ & $\mathbf{2 0 1 9}$ & $\mathbf{2 0 2 0}$ & $\mathbf{2 0 1 9}$ & $\mathbf{2 0 2 0}$ & $\mathbf{2 0 1 9}$ & $\mathbf{2 0 2 0}$ \\
\hline Seedling 1 & 68.06 & 67.70 & 56.18 & 55.79 & 39.18 & 38.27 & 0.073 & 0.087 & 16.99 & 17.52 \\
Seedling 2 & 61.83 & 63.26 & 51.26 & 51.24 & 35.26 & 35.82 & 0.062 & 0.057 & 15.99 & 15.42 \\
Seedling 3 & 70.20 & 71.26 & 63.00 & 63.64 & 41.45 & 41.86 & 0.053 & 0.049 & 21.54 & 21.78 \\
Seedling 4 & 74.26 & 74.66 & 64.69 & 64.91 & 43.38 & 43.84 & 0.062 & 0.059 & 21.30 & 21.06 \\
Seedling 5 & 65.23 & 64.80 & 59.42 & 58.53 & 40.46 & 38.04 & 0.062 & 0.068 & 18.96 & 20.48 \\
Seedling 6 & 70.43 & 69.20 & 60.45 & 60.97 & 44.34 & 43.82 & 0.077 & 0.081 & 16.11 & 17.15 \\
Seedling 7 & 72.63 & 71.80 & 59.88 & 59.27 & 38.76 & 38.24 & 0.053 & 0.059 & 21.12 & 21.03 \\
Seedling 8 & 76.30 & 75.53 & 64.36 & 64.00 & 44.58 & 44.48 & 0.068 & 0.075 & 19.78 & 19.52 \\
Seedling 9 & 70.23 & 70.63 & 60.36 & 60.85 & 41.68 & 41.84 & 0.056 & 0.060 & 18.67 & 19.01 \\
Bartamuda cv. & 73.03 & 72.70 & 68.66 & 68.10 & 44.47 & 44.10 & 0.044 & 0.042 & 24.19 & 24.00 \\
\hline LSD 5\% & 0.51 & 0.98 & 0.67 & 0.37 & 0.62 & 1.59 & 0.017 & 0.017 & 1.04 & 1.39 \\
\hline
\end{tabular}

Bartamuda cv., followed by the third and fourth strains recorded the highest percentage of nonreducing sugars as an average of two seasons compared to other date palm. While the lowest level of non- reducing sugars was recorded with the second and sixth, and then the first strains in the two study seasons. Among the chemical characteristics of the fruit, the total acidity percentage, this was observed to be at the lowest level with Bartamuda $(0.044 \& 0.042 \%)$, then the third and seventh strains. Meanwhile, the highest level was recorded with the first and sixth ones.

From the obtained data of this study, we could notice that there were differences among Bartamuda c.v and the strains under study in their chemical characteristics specially sugars content, Bartamuda c.v surpassed the seedy strains, meanwhile the differences in total acidity were non significant (Khalil, 2005) and Metwally et al. (2019).

\subsection{Physical characteristics of fruits}

Physical characteristics of the nine studied seedling strains as compared to Bartamuda cv. as dry date palm in Aswan during 2019 and 2020 were shown in Table (5). The differences were significant between the physical parameters of the studied palms for both seasons. However, the highest values of the fruit weight were noticed with strain No. 6 (9.55 \& 10.53), No. 8 (8.11 \& 8.51), No. 3 (8.18 \& 7.83) and No. $1(7.98 \& 7.80 \mathrm{~g})$ compared to Bartamuda $(6.28 \& 5.61 \mathrm{~g})$ in the first and second seasons, respectively. The first and eighth, followed by sixth strains recorded the highest values of seed weight, while the fourth, third and ninth ones recorded the lowest values compared to other palms in the average seasons. On the other hand, some of seedy strains were superior to Bartamuda palm for the flesh weights such as strain No. 6 (8.18 \& 9.10), strain No. 3 (7.15 \& 6.73) and No. 8 (6.71 \& 7.05 g) compared with 
Bartamuda cv. (5.32 \& $4.38 \mathrm{~g}$ ) in the two seasons, respectively. When comparing the average fruit length of the palm fruits, it became clear that, the sixth, followed by the second and seventh strains were the highest in fruit length compared to other palms. Meanwhile, the lowest fruit length was recorded with the fifth, ninth, and Bartamuda palms in the average of seasons. Also, among the physical characteristics that showed superiority of some seedy strains compared to Bartamuda cv, the fruit diameter as strain No. $6(2.53 \& 2.83)$, No. $1(2.50 \& 2.43)$ and No. $4(2.46 \& 2.20 \mathrm{~cm})$ in the two seasons, respectively.

Among the physical characteristics that showed superiority in fruits of some seedy strains, thefruit weight, flesh weight, and length in compared to Bartamuda. The highest values of the fruit weight were noticed with the sixth, eighth, third, and first strains compared to Bartamuda. The same results were reported by Hussein and Hussein (1982a);Abdalla et al. (1993); El-Agamy et al.(2001); Gadalla (2003); Khalil (2005); Metwally et al. (2019).

Table 5: Physical characteristics of fruits of certain seeded dry palms and Bartamuda cv. during 2019 and 2020 seasons.

\begin{tabular}{ccccccccccc}
\hline $\begin{array}{c}\text { Character } \\
\text { Seedling No }\end{array}$ & $\begin{array}{c}\text { Fruit weight } \\
\text { (g) }\end{array}$ & \multicolumn{2}{c}{$\begin{array}{c}\text { Seed weight } \\
\text { (g) }\end{array}$} & \multicolumn{2}{c}{$\begin{array}{c}\text { Flesh weight } \\
\text { (g) }\end{array}$} & \multicolumn{2}{c}{$\begin{array}{c}\text { Fruit length } \\
\text { (cm) }\end{array}$} & \multicolumn{2}{c}{$\begin{array}{c}\text { Fruit diameter } \\
\text { (cm) }\end{array}$} \\
\hline & $\mathbf{2 0 1 9}$ & $\mathbf{2 0 2 0}$ & $\mathbf{2 0 1 9}$ & $\mathbf{2 0 2 0}$ & $\mathbf{2 0 1 9}$ & $\mathbf{2 0 2 0}$ & $\mathbf{2 0 1 9}$ & $\mathbf{2 0 2 0}$ & $\mathbf{2 0 1 9}$ & $\mathbf{2 0 2 0}$ \\
\hline Seedling 1 & 7.98 & 7.80 & 1.61 & 1.58 & 6.40 & 6.36 & 5.80 & 5.50 & 2.50 & 2.43 \\
Seedling 2 & 6.60 & 6.45 & 1.16 & 1.26 & 5.43 & 5.18 & 6.86 & 6.23 & 2.06 & 1.86 \\
Seedling 3 & 8.18 & 7.83 & 1.03 & 1.10 & 7.15 & 6.73 & 5.83 & 5.40 & 2.00 & 2.20 \\
Seedling 4 & 6.50 & 5.75 & 0.96 & 1.06 & 5.20 & 4.68 & 6.23 & 6.03 & 2.46 & 2.20 \\
Seedling 5 & 5.08 & 5.21 & 1.13 & 1.10 & 3.95 & 4.11 & 4.76 & 5.03 & 2.13 & 2.26 \\
Seedling 6 & 9.55 & 10.53 & 1.36 & 1.43 & 8.18 & 9.10 & 6.40 & 6.90 & 2.53 & 2.83 \\
Seedling 7 & 6.83 & 6.93 & 1.26 & 1.33 & 5.56 & 5.56 & 6.13 & 6.60 & 2.03 & 2.30 \\
Seedling 8 & 8.11 & 8.51 & 1.40 & 1.46 & 6.71 & 7.05 & 5.96 & 6.30 & 2.03 & 2.36 \\
Seedling 9 & 4.24 & 4.03 & 1.16 & 1.20 & 3.05 & 2.83 & 5.00 & 4.80 & 2.13 & 1.93 \\
Bartamuda cv. & 6.28 & 5.61 & 1.30 & 1.23 & 5.31 & 4.38 & 5.36 & 5.06 & 2.06 & 1.67 \\
\hline LSD 5\% & 1.06 & 0.96 & 0.10 & 0.07 & 1.02 & 0.95 & 0.24 & 0.187 & 0.14 & 0.162 \\
\hline
\end{tabular}

3.5. Total score for the seedy strains and Bartamuda

Data in Table (6) showed that growing Bartamuda cv. in Bamban village in the city of Daraw, Aswan Governorate was superior in terms of productivity and quality as it attained the uppermost score units(90.00) compared to other seedy strains in the same region.

Table 6: General score evaluation of fruit of certain seedy dry date palm and Bartamuda cv. grown in Aswan in the average of two seasons.

\begin{tabular}{|c|c|c|c|c|c|c|c|c|c|c|c|}
\hline \multicolumn{12}{|c|}{ Average of $2019 \& 2020$ seasons } \\
\hline Index & $\begin{array}{c}\text { Units } \\
\text { specified }\end{array}$ & $\begin{array}{c}\text { Strain } \\
1\end{array}$ & $\begin{array}{l}\text { Strain } \\
\quad 2\end{array}$ & $\begin{array}{c}\text { Strain } \\
\mathbf{3}\end{array}$ & $\begin{array}{l}\text { Strain } \\
4\end{array}$ & $\begin{array}{l}\text { Strain } \\
5\end{array}$ & $\begin{array}{l}\text { Strain } \\
6\end{array}$ & $\begin{array}{c}\text { Strain } \\
7\end{array}$ & $\begin{array}{l}\text { Strain } \\
8\end{array}$ & $\begin{array}{c}\text { Strain } \\
9\end{array}$ & $\begin{array}{c}\text { Bartamuda } \\
\text { c.v }\end{array}$ \\
\hline Yield & 30 & 30 & 22 & 25 & 25 & 22 & 22 & 24 & 24 & 24 & 30 \\
\hline T.S.S.\% & 10 & 7 & 6 & 7 & 10 & 6 & 6 & 7 & 10 & 7 & 8 \\
\hline Total sugars $\%$ & 10 & 6 & 6 & 7 & 8 & 6 & 6 & 6 & 8 & 6 & 10 \\
\hline Total acidity \% & 10 & 7 & 8 & 9 & 8 & 8 & 7 & 9 & 8 & 8 & 10 \\
\hline Fruit weight & 10 & 10 & 8 & 10 & 8 & 7 & 10 & 8 & 10 & 7 & 8 \\
\hline Seed weight & 10 & 7 & 9 & 10 & 10 & 9 & 8 & 8 & 7 & 9 & 8 \\
\hline Flesh weight & 10 & 10 & 8 & 10 & 8 & 7 & 10 & 8 & 10 & 7 & 8 \\
\hline Fruit length & 5 & 4 & 5 & 4 & 5 & 4 & 5 & 5 & 5 & 4 & 4 \\
\hline Fruit diameter & 5 & 5 & 4 & 5 & 5 & 5 & 5 & 5 & 5 & 5 & 4 \\
\hline $\begin{array}{l}\text { Total scour fruit } \\
\text { quality }\end{array}$ & 70 & 56 & 54 & 62 & 62 & 52 & 57 & 56 & 63 & 53 & 60 \\
\hline $\begin{array}{l}\text { Total unit yield/ } \\
\text { palm }\end{array}$ & 100 & 86 & 76 & 87 & 87 & 74 & 79 & 80 & 87 & 77 & 90 \\
\hline
\end{tabular}


The superiority was in the units of the yield, percentage of total sugars, lowest total acidity. In spite of the superiority of the Bartamuda cv., there were certain seedy strains that have high production and quality characteristics such as the third (87.00), fourth (87.00), eighth (87.00), and the first (86.00). On the other hand, there are some strains that resulted in lowest values when evaluated in compared to the Bartamuda, such as the fifth (74.00), second (76.00) and ninth strains (77.00).

Bartamuda cv. was superior in terms of productivity and qualityas it attained the uppermost score units (90.00) compared to other seedy strains in the same region. Meanwhile, it could be concluded that there were some palms that gave high productivity and quality, such as the third, fourth, eighth, and the first strains.

\section{Conclusion}

From the obtained results, it could be concluded that, in Bamban region there were some seedy strains of dry date palms which surpassed Bartamuda c.v in their both of physical and chemical characters .Such strains must be take more of care from researchers in the future studies and try to spread cultivation of them through offshoots produced via tissue culture technique.

\section{References}

A.O.A.C. Association of Official Agricultural Chemists, 1995. Official Methods of Analysis A.O.A.C. Benjamin Franklin Station, Washington D.C. MSA. pp. 440-512.

Abdalla, K. M., F. Hussein and A.S. Khalifa, 1993. Evaluation of productive and fruit characteristics of some Egyptian date cultivars grown at Aswan. The $3^{\text {rd }}$ Symposium on Date Palm, (12-20 Jan.) KFU, Al-Hassa, Kingdom of Saudi Arabia, pp. 575-584.

Abdalla, M. Y., 1986. Morphological and chemical studies through flowering and fruiting stages on date palm. Ph. D. Thesis. Fac, Agric., Cairo Univ., 190p.

Abd-El Hamed, K., Rasmia S.S. Darwesh and Eman M.M. Zayed, 2017. Evaluation Physical and Chemical Characteristics of Some Seedlings Date Palm Fruits (Maghal) in the North Delta Egypt. Inter. J. Advanc.Agric. Sci. and Techn., 4 (7): 13-32.

El-Agamy S. Z., T.K. El-Mahdy and O.A. Khalil, 2001. Behaviour studies of Dajana and Sakkoti date palm cultivars under Aswan environment. The Second International Conference on Date Palms. Al-Ain, United Arab of Emarates, March 25-27 (In Press).

El-Salhy, A.M., Ibrahim, R.A., E.G. Gadalla and H.K.H. Khalil, 2016. Evaluation of Some Seeded Dry Date Palm Grown Under Aswan Climatic Condition. Assiut J. Agric. Sci., (47) No. (4) (136155).

El-Sharabasy, S.F., E.T. El-Baz, O.H. El-Shiaty and F. Fawzi, 2003. Evaluation of nine seedling date palm (Phoenix dactylifera L.) males in pollination of Zaghloul date palm cultivar. Zagazig J. Agric. 30 (4): 1463-1475.

Gadalla, E., 2003. Propagation of dry varieties of date palm. Ph. D. Thesis, Fac. Agric. Cairo Univ.

Gadalla, E. G., 2013. Selection and evaluation of some superior date palm strains growing in Aswan Governorate'. Egypt. J. of Appl. Sci., 28 (8): 454-481

Hussein, F., 1970. Fruit growth and composition of two dry date cultivars at Aswan. Trop. Agric. Trin 47 (2): 157-162.

Hussein, F., and M.A. Hussein, 1982a. Effect of irrigation on growth, yield and fruit quality of dry dates grown at Asswan. First Symposium on Date Palm in Al-Hassa, Saudi Arabia. 169-173.

Hussein, F., M.S. El-Khatitany and Y.A. Wally, 1979. Date palm growing and date production in the Arab and Islamic World. Ain Shams Press (In Arabic), Egypt.

Ismail, B., I. Hoffar, R. Baalbaki, Y. Mechref and J. Henry, 2006. Physico-chemical characteristics and total quality of five date varieties grown in the United Arab Emirates'. International J. of Food Sci. and Technology, 41 (8): 919.

Jaradate, A.A. and A. Zaid, 2004. Quality traits of date palm fruits in a center of origin and center of diversity. International J. of Food, Agric. and the Environment, 2 (1): 208-217.

Khalil, O. A., 1999. Behaviour studies on some soft and dry date cultivars under Aswan environment. M. Sc. Thesis, Fac. Agric. Assiut Univ. 
Khalil, O. A., 2005. Comparative studies on sexually and vegetatively propagated date palms under Aswan environmental conditions. Ph. D. Thesis, Fac. Agric. Assiut Univ.

Khayyat, M., E. Tafazoli, S. Eshaghi and S. Rajaee, 2007. Effect of nitrogen, boron, potassium and zinc sprays on yield and fruit quality of date palm'. American Eurasian J. Agric. \& Environ. Sci., 2 (3): 289296.

Mawlood, E. A., 1980. Physiological studies on fruits development of Samani and Zaghloul date palm cultivars'. Ph.D. Thesis. Hort. Dept. Agric. Fac. Cairo. Univ. Egypt pp. 110.

Metwally, H.A.A., A.A. El-Bana, Y.S. Tahany and Y.M. Diab, 2019. Evaluation of Some Selected Seeded Date Palms and Determination of its Fruit Characteristics under Dakhla Oasis Conditions -New Valley- Egypt. Middle East J. Appl. Sci., 9(3): 711-726.

Nour, G. M., A.S. Khalifa, A.A.M. Hussein and A.A. Moustafa, 1986. Studies on the evaluation of fruit characteristics on nine dry date palm cultivars grown at Aswan. The $2^{\text {nd }}$ Symposiumon Date Palm, King Faisal Univ., Al-Hassa, Saudi Arabia, pp. 163-171.

Rokba, S.A. and A.I. Abou El-Azayem, 1990. Biological studies on some date palm seedling grown in Fayoum Governorate. J. Agric. Sci. Mansoura, Univ. 15(2):232-238pp

Shabana, H. R. and N.S. Antoun, 1980. The determination of leaf area in date palm Beitroyazur Tropischen Land Wirtschaft and Veterinar Medizin, 18 (4): 345349. (C.F. Hort. Abst. 51: 9012).

Snedecor, G.W. and W.G. Cochran, 1980. Statistical Methods. Oxford and J.B.H. publishing Com. $6^{\text {th }}$ edition. 